The $6^{\text {th }}$ Conf. of SSFOP “Sustainable Development of Ornamental, Medicinal and Aromatic

Plants Scope”, Cairo, Egypt, 1/3/2020

Scientific J. Flowers \& Ornamental Plants

www.ssfop.com/journal

ISSN: 2356-7864

doi: 10.21608/sjfop.2020.91393

\title{
PHYSIOLOGICAL RESPONSE OF GAZANIA PLANTS TO GROWING MEDIA AND ORGANIC COMPOST
}

\author{
A.H. El-Naggar*; T.M. El-Kiey ${ }^{*}$; E. Koreish ${ }^{* *}$ and N.M. Zaid* \\ * Floriculture, Ornamental Horticulture and landscape Gardening Dept., Fac. of Agric., (EL-Shatby), \\ Alexandria Univ. Egypt \\ ** Soil and Water Sciences Dept., Fac. of Agric., (EL-Shatby), Alexandria Univ. Egypt
}

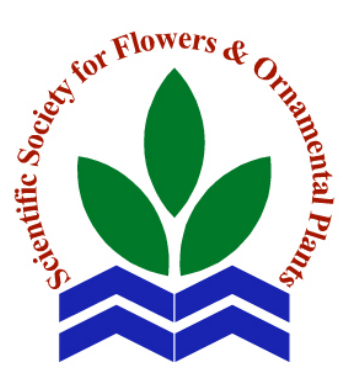

ABSTRACT: This work was carried out during two successive
seasons of 2017 and 2018 at the Nursery, Department of Floriculture,
Ornamental Horticulture and Landscape Gardening, Faculty of
Agriculture, Alexandria University, Egypt to investigate the effect of
different growing media (calcareous + sand + peat moss at the rate 70
and $40 \%$ ) and two types of organic compost (rice straw and sugar beet
at 30 and $60 \%$ ) and their interaction on the growth and flowering of
Gazania splendens plants. The experimental design in split-plot
arrangement, with four replications, in both seasons. The growing
media were laid out in the main plots and sub-plots included the
different organic composts. Three pots were used as a plot for each
treatment. The means of the individual factors and their interactions
were compared by L.S.D. test at $5 \%$ level of probability. The obtained
results can be summarized as follows; most vegetative growth
characteristics such as: number of tillers (54.74), number of leaves
(239.76) and leaves fresh weight (100.29 g) were significantly affected
by organic compost at $60 \%$ sugar beet with peat moss treatment,
flowers characteristics (inflorescences diameter (9.34 cm) and number Scientific J. Flowers \& of inflorescences (14.87), and inflorescences dry weights (0.459 g), Ornamental Plants, responded significantly to the interaction between the different media 7(1):11-26 (2020).

Received:

$13 / 1 / 2020$

Accepted:

$10 / 2 / 2020$ and organic compost, the highest significant values were obtained by organic compost at 30 and/ or $60 \%$ sugar beet and peat moss. Total chlorophyll (56.23 mg/g f.w.), nitrogen (3.42\%), phosphorus (0.74\%) in the leaves were the highest with $60 \%$ sugar beet and $40 \%$ peat moss in both seasons. However, potassium (2.85\%) in the leaves gave the highest significant values by $60 \%$ sugar beet with calcareous soil (40\%) for both seasons. It can be recommended that producing high quality of Gazania splendens plants for different decorative purposes in landscaping can be accomplished by growing plants in the mixture of peat moss (40\%) with organic compost at rate $60 \%$ sugar beet led to improve its characteristics.

Key words: Gazania, growing media, organic compost, soil amendments, sugar beet, rice straw, perennial plants, Asteraceae. 


\section{A.H. El-Naggar et al.}

\section{INTRODUCTION}

Gazania rigens (G. splendens) is an herbaceous perennial plant named for a flower shape resembling a medal (Zeng et al., 2016). It is a member of the family Asteraceae, native to South Africa. This plant has become very attractive to domestic producers in the last few years because of its ornamental and medicinal properties, the plants prefer a sunny locations and are tolerant of dryness and poor soils. Plants are salt tolerant and can be used in coastal regions very effectively (Ball, 1991). It is spreading low-growing, half-hardy perennial, growing to $50 \mathrm{~cm}$ (20 in) tall and wide, with blue-grey foliage and brilliant yellow, daisy-like composite flower heads throughout the summer (Sardoei et al., 2014).

Most of the newly reclaimed soils in Egypt are sandy and calcareous soils that are of poor available nutrients, to increase their productivity, organic matter application plays an important role to retain the inorganic elements in complex and chelate forms. In this accord, organic manures are well established to be involved in fertilization of plants in almost worldwide, due to their beneficial effects on soil physico-chemical and biological characteristics, which in turn influence the growth and increase plants production (Youssef et al., 2001).

The utilization of agricultural wastes in producing organic fertilizers minimizes the environmental pollution and overcomes the organic matter deficiency. Recycling the agricultural wastes through composting process under aerobic conditions converts them to stabilized and useful compost product (Osman et al., 2008). In Egypt, recycling rice straw and organic wastes is of great concern as well as improvement of soil properties. Rice straw compost could improve both organic waste recycling and soil quality. Rice straw has become a very serious problem in Egypt due to the huge production of straw of about 20 million tons yearly. Being a suitable material for insects and pests, rice straw is considered a problem for the farmers who store it near their houses or fields. The farmers then burn the straw causing black clouds and severe pollution in the Egyptian atmosphere (Afify et al., 2002).

Soil amendments are offered with the promise of improving soil fertility characteristics, such as reducing or eliminating the need for fertilizer elements, making native soil elements more available to plants, providing balanced soil fertility, or inoculating soil with proper or improved strains of bacteria, enzymes or hormones (Davis and Wilson, 2005). Sugar beet residual compost is processed as a local organic material. Sugar beet residual compost is an important issue in ornamental plants production. (Soliman, 2005), mainly due to its enrichment with $\mathrm{S}, \mathrm{N}, \mathrm{P}$ and $\mathrm{K}$ mineral elements. Composting is generally defined as the biological oxidative decomposition of organic constituents in wastes under controlled conditions which allow development of aerobic microorganisms that convert biodegradable organic matter into a final product sufficiently stable for storage and application without adverse environmental effects. The main products of aerobic composting are $\mathrm{CO}_{2}, \mathrm{H}_{2} \mathrm{O}$, mineral ions and humus. During composting, organic matter is transformed into a humus-rich product by the action of microorganisms and their enzymes (VargasGarcia et al., 2010). Microbes and their secreted enzymes play a key role in biological and bio-chemical transformations of compost matrixes in the composting process (Guo et al., 2012).

So, the main objective of the present investigation was to evaluate the individual and combined effects of three selected growing media and two selected organic compost throughout the growing seasons on growth, flowering as well as the chemical constitutes of Gazania plants.

\section{MATERIALS AND METHODS}

The pot experimental was carried out during two successive growing seasons of 
2017 and 2018 at the Nursery, Department of Floriculture, Ornamental Horticulture and Landscape Gardening, Faculty of Agriculture, Alexandria University, Egypt. The rooted cuttings of Gazania splendens were obtained from the Nursery, Department of Floriculture, Ornamental Horticulture and Landscape Gardening, Faculty of Agriculture, Alexandria University, Egypt. These rooted cuttings were similar in their shape and size with an average length of 10 $\mathrm{cm}$ and contained 5 leaves for each one. The rooted cuttings were transplanted on $10^{\text {th }}$ April for the two seasons in $25 \mathrm{~cm}$ diameter clay pots (one plant/pot) using the different growing media. The planted Gazania were placed in a partial shade place for three weeks and watered as needed according to the climatic conditions. These plants were left for another 45 days after planting to grow vegetatively by early removing all formed flower buds, then they were arranged in the experiment. Calcareous soil was brought from the Northern Western Coast $37.5 \mathrm{~km}$ far off Alexandria City, while, sandy soil was brought from a sand storehouse in Alexandria city. Peat moss was brought from a commercial store in Alexandria city. Then it was mixed with different ratios (30\% and 60\%) of the two organic compost, sugar beet compost and rice straw compost. Rice straw compost was obtained from Rice Research and Training Center (RRTC), Sakha, Kafr El-Sheikh, Egypt. Sugar beet compost was obtained from El Noor for Chemicals and Fertilizers, Industrial zone, Nubariya, Cairo-Alexandria desert road, Egypt. Chemical analysis of the two organic compost are presented in Table (1), Physical and chemical properties of the growing media used in the study are presented in Table (2). The components of the used organic compost treatments are shown in Table (3).

The degree of air temperature and relative humidity (\%) at the Nursery, Department of Floriculture, Ornamental Horticulture and Landscape Gardening, Faculty of Agriculture, Alexandria University, Egypt. districts were recorded daily during the growing period of two seasons (6 months) for each and the monthly average of them are presented in Table (4).

Table 1. Chemical analysis of the organic materials.

\begin{tabular}{lccccc}
\hline Organic materials & C \% & N \% & C:N Ratio & P \% & K \% \\
Rice straw compost & 30 & 1.80 & 16.67 & 0.59 & 0.81 \\
Sugar beet compost & 11.05 & 0.56 & 20 & 0.57 & 0.75 \\
\hline
\end{tabular}

Table 2. Some physical and chemical characteristics of sand, calcareous soil and peatmoss.



*Saturated soil paste extract. 
A.H. El-Naggar et al.

Table 3. The components of the used organic compost treatments.

\begin{tabular}{llll}
\hline \multicolumn{1}{c}{ Treatment No. } & $\begin{array}{l}\text { Medium components } \\
\text { Sandy soil }\end{array}$ & Calcareous soil & Peat moss \\
\hline OC $_{\mathbf{T 1}}$ & $100 \%$ & $100 \%$ & $100 \%$ \\
OC $_{\mathbf{T} 2}$ & $30 \%$ rice straw compost $+70 \%$ & $30 \%$ rice straw compost + & $30 \%$ rice straw compost + \\
& sandy soil & $70 \%$ calcareous soil & $70 \%$ peat moss \\
OC $_{\mathbf{T} 3}$ & $60 \%$ rice straw compost $+40 \%$ & $60 \%$ rice straw compost + & $60 \%$ rice straw compost + \\
& sandy soil & $40 \%$ calcareous soil & $40 \%$ peat moss \\
OC $_{\mathbf{T} 4}$ & $30 \%$ sugar beet compost $+70 \%$ & $30 \%$ Sugar beet compost + & $30 \%$ sugar beet compost + \\
& sandy soil & $70 \%$ calcareous soil & $70 \%$ peat moss \\
OC $_{\mathbf{T} 5}$ & $60 \%$ sugar beet compost $+40 \%$ & $60 \%$ sugar beet compost + & $60 \%$ sugar beet compost + \\
& sandy soil & $40 \%$ calcareous soil & $40 \%$ peat moss \\
\hline
\end{tabular}

Table 4. The average temperature throughout the growing period of Gazania plants during the two seasons of 2017 and 2018 at Elshatby, Alexandria Governorate.

\begin{tabular}{|c|c|c|c|c|c|c|}
\hline \multirow{3}{*}{ Month } & \multicolumn{3}{|c|}{ First season 2017} & \multicolumn{3}{|c|}{ Second season 2018} \\
\hline & \multicolumn{2}{|c|}{ Temperature $\left({ }^{\circ} \mathrm{C}\right)$} & \multirow{2}{*}{$\begin{array}{c}\text { Relative humidity } \\
\text { (\%) }\end{array}$} & \multicolumn{2}{|c|}{ Temperature $\left({ }^{\circ} \mathrm{C}\right)$} & \multirow{2}{*}{$\begin{array}{c}\text { Relative humidity } \\
\text { (\%) }\end{array}$} \\
\hline & Min. & Max. & & Min. & Max. & \\
\hline April & 16 & 27 & 54 & 17 & 28 & 60 \\
\hline May & 19 & 29 & 53 & 20 & 32 & 61 \\
\hline June & 23 & 31 & 57 & 24 & 31 & 59 \\
\hline July & 27 & 32 & 56 & 25 & 33 & 64 \\
\hline August & 30 & 33 & 58 & 30 & 33 & 62 \\
\hline September & 25 & 36 & 53 & 26 & 29 & 60 \\
\hline October & 20 & 28 & 51 & 21 & 29 & 63 \\
\hline November & 17 & 21 & 56 & 17 & 26 & 58 \\
\hline
\end{tabular}

The experimental layout was designed to provide split plot design containing four replicates. Main plot was the different media, while organic compost treatments were the sub plot. Each replicate contained 15 treatments (5 organic compost treatments $\times 3$ different media). Three pots were used as plot for each treatment. The means of the individual factors and their interactions were compared by L.S.D. test at $5 \%$ level of probability (Gomez and Gomez, 1984).

Data recorded for the vegetative growth parameters included; number of tillers, number of leaves, leaves fresh weight (g) and total plant fresh weight (g). The flowering data were; inflorescences diameter (cm), number of inflorescences and inflorescences dry weights (g). Data recorded for the chemical composition included; leaf total chlorophyll content (SPAD units) were measured according to method described by (Yadava, (1986) using Minolta SPAD chlorophyll Meter Model No. 502. The nitrogen $(\%)$ of the dried leaves was determined according to methods described by Evenhuis and Dewaard, (1980). While the potassium and phosphorus (\%) were determined according to the method described by Chapman and Pratt (1961).

\section{RESULTS AND DISCUSSION}

\section{Vegetative growth characteristics:}

\section{Number of tillers/plant:}

Data presented in Table (5) showed that media had insignificant effects on that trait in the two seasons of study, while compost treatments and the interaction between media and compost treatments had significant effect on number of tillers/plant in the two seasons of study. With regard to different media, the results presented in Table (5) showed that calcareous and peat moss media 
Table 5. Effect of different media, organic compost and their interaction on number of tillers/plant of Gazania splendens during 2017 and 2018 seasons.

\begin{tabular}{|c|c|c|c|c|}
\hline \multirow{2}{*}{$\begin{array}{l}\text { Organic } \\
\text { compost } \\
\text { treatments } \\
\text { (B) } \\
\end{array}$} & \multicolumn{3}{|c|}{ Media (A) } & \multirow[b]{2}{*}{$\begin{array}{c}\text { Mean } \\
\text { (B) }\end{array}$} \\
\hline & Sandy & Calcareous & $\begin{array}{l}\text { Peat } \\
\text { moss }\end{array}$ & \\
\hline & \multicolumn{4}{|c|}{ First season } \\
\hline $\mathrm{OC}_{\mathrm{T} 1}$ & 13.13 & 13.52 & 11.67 & 12.77 \\
\hline $\mathrm{OC}_{\mathrm{T} 2}$ & 15.44 & 17.20 & 16.15 & 16.27 \\
\hline $\mathrm{OC}_{\mathrm{T} 3}$ & 16.42 & 17.01 & 21.59 & 18.34 \\
\hline $\mathrm{OC}_{\mathrm{T} 4}$ & 15.93 & 22.91 & 18.37 & 19.07 \\
\hline $\mathrm{OC}_{\mathrm{T} 5}$ & 22.37 & 20.83 & 24.16 & 22.46 \\
\hline Mean (A) & 16.66 & 18.30 & 18.39 & \\
\hline \multirow[t]{2}{*}{$\underline{\text { LSD }_{0.05}}$} & $A=N . S$ & $\mathrm{~B}=1.57$ & $A \times B=2.7$ & \\
\hline & \multicolumn{4}{|c|}{ Second season } \\
\hline $\mathrm{OC}_{\mathrm{T} 1}$ & 16.62 & 17.12 & 14.77 & 16.17 \\
\hline $\mathrm{OC}_{\mathrm{T} 2}$ & 19.55 & 21.77 & 20.44 & 20.59 \\
\hline $\mathrm{OC}_{\mathrm{T} 3}$ & 20.79 & 21.53 & 27.33 & 23.22 \\
\hline $\mathrm{OC}_{\mathrm{T} 4}$ & 20.17 & 29.00 & 23.25 & 24.14 \\
\hline $\mathrm{OC}_{\mathrm{T} 5}$ & 28.32 & 26.37 & 30.58 & 28.43 \\
\hline Mean (A) & 21.09 & 23.16 & 23.28 & \\
\hline LSD0.05 & $A=N . S$ & $\mathrm{~B}=1.99$ & $\mathrm{~A} \times \mathrm{B}=3.4$ & \\
\hline
\end{tabular}

* N.S: not significant.

gave higher, though insignificant, number of tillers/plant than sandy soil in both seasons. Means of organic compost treatments at $60 \%$ sugar beet produced the highest number of tillers/plant as 22.46 and 28.43 in the two successive seasons, respectively, while the lowest values resulted from the treatment without any organic compost as 12.77 and 16.17 tillers/plant in both seasons, respectively. For the interaction effect on that character, organic compost treatments gave different values with the media used. $\mathrm{OC}_{\mathrm{T} 1}$ gave low number of tillers/plant with all media. Moreover, $\mathrm{OC}_{\mathrm{T} 3}$ gave statistically similar values in sandy and calcareous media, while it gave significantly higher value with peat moss. $\mathrm{OC}_{\mathrm{T} 4}$ had significantly low value in sandy medium as 15.93, 20.17 as compared to calcareous (22.91, 29.00), which was, also significantly higher than peat moss (18.37, 23.25). The highest values of 24.16 and 30.58 were obtained using $\mathrm{OC}_{\mathrm{T} 5}$ and peat moss, in the two seasons, respectively. This improvement in the number of tillers/plant may be attributed to some changes in soil physical and chemical properties of the media through increasing the organic matter and supplying the peat moss. These results were in agreement with those obtained by Singh (1999) on wheat and El-Nady (2015) on Cymbopogon flexuosus plants.

\section{Number of leaves/plant:}

Data presented in Table (6) showed that peat moss and calcareous gave high number of leaves/plant with values of 176.12, 222.94 in peat moss and 170.82, 216.23 in calcareous medium than sandy soil, in the two seasons, respectively. Means of compost treatments either $30 \%$ or $60 \%$ sugar beet compost produced the highest number of leaves as 202.97, 256.93 and 192.57, 243.76 in the two seasons, respectively, as compared to the other compost treatments. Concerning the interaction between the two studied factors, i.e. organic compost and media, data showed that $\mathrm{OC}_{\mathrm{T} 1}$ produced the lowest number of leaves/plant with all media in the two seasons. Moreover, $\mathrm{OC}_{\mathrm{T} 3}$ showed insignificant response to type of media.

Table 6. Effect of different media, organic compost and their interaction on number of leaves/plant of Gazania splendens during 2017 and 2018 seasons.

\begin{tabular}{|c|c|c|c|c|}
\hline \multirow{2}{*}{$\begin{array}{l}\text { Organic } \\
\text { compost } \\
\text { treatments } \\
\text { (B) }\end{array}$} & \multicolumn{3}{|c|}{ Media (A) } & \multirow[b]{2}{*}{$\begin{array}{c}\text { Mean } \\
\text { (B) }\end{array}$} \\
\hline & Sandy & Calcareous & $\begin{array}{l}\text { Peat } \\
\text { moss }\end{array}$ & \\
\hline & \multicolumn{4}{|c|}{ First season } \\
\hline $\mathrm{OC}_{\mathrm{T} 1}$ & 95.33 & 123.10 & 119.22 & 112.54 \\
\hline $\mathrm{OC}_{\mathrm{T} 2}$ & 108.23 & 145.10 & 174.42 & 142.58 \\
\hline $\mathrm{OC}_{\mathrm{T} 3}$ & 186.58 & 191.97 & 178.87 & 185.81 \\
\hline $\mathrm{OC}_{\mathrm{T} 4}$ & 187.85 & 224.61 & 196.45 & 202.97 \\
\hline $\mathrm{OC}_{\mathrm{T} 5}$ & 196.71 & 169.35 & 211.63 & 192.57 \\
\hline Mean (A) & 154.94 & 170.82 & 176.12 & \\
\hline \multirow[t]{2}{*}{$\mathbf{L S D}_{0.05}$} & $A=14.75$ & $5 \quad B=14.07$ & $\mathrm{~A} \times \mathrm{B}=2$ & 4.39 \\
\hline & \multicolumn{4}{|c|}{ Second season } \\
\hline $\mathrm{OC}_{\mathrm{T} 1}$ & 120.67 & 155.78 & 150.91 & 142.46 \\
\hline $\mathrm{OC}_{\mathrm{T} 2}$ & 137.00 & 183.66 & 220.78 & 180.48 \\
\hline $\mathrm{OC}_{\mathrm{T3}}$ & 236.18 & 243.00 & 226.42 & 235.20 \\
\hline $\mathrm{OC}_{\mathrm{T} 4}$ & 237.78 & 284.32 & 248.67 & 256.93 \\
\hline $\mathrm{OC}_{\mathrm{T} 5}$ & 249.00 & 214.37 & 267.89 & 243.76 \\
\hline Mean (A) & 196.13 & 216.23 & 222.94 & \\
\hline LSD $_{0.05}$ & $A=18.67$ & $7 \quad \mathrm{~B}=17.81$ & $\mathrm{~A} \times \mathrm{B}=3$ & 0.88 \\
\hline
\end{tabular}


However, $\mathrm{OC}_{\mathrm{T}}$ gave low values in sandy and peat moss media compared to calcareous. $\mathrm{OC}_{\mathrm{T} 5}$ gave significantly higher number of leaves/plant in peat moss medium (211.63 and 267.89, respectively) as compared to the calcareous soil. This increase in the leaves number of gazania plants may be due to cell multiplication, cell enlargement and cell differentiation, which have resulted in increasing number and area of the leaves, and it may have been related to the favorable effects of such amendments on soil physical and chemical properties besides their nutrients content. Many researches obtained similar results as Sherif and ELNaggar (2005) on Zantedeschia aethiopica, and Soliman et al. (2013) on Gardenia jasminoides.

\section{Leaves fresh weight/plant (g):}

Data presented in Table (7) showed that calcareous and peat moss gave highest values of 54.99,70.51 g and 54.25,69.55 g, respectively, in the both seasons, whereas the lowest values were recorded in sandy soil. Means of compost treatments indicated that organic compost at $60 \%$ sugar beet produced the highest leaves fresh weight/plant as 74.89 and $96.02 \mathrm{~g}$ in both seasons, respectively, while the lowest values resulted from the treatment without any organic compost $\mathrm{OC}_{\mathrm{T} 1}$ giving values of 30.13 and 38.63 g, respectively, in the two seasons. For the interactions effect on the leaves fresh weight/plant (g), means presented in Table (7) showed that organic compost treatments gave different values with the media used. $\mathrm{OC}_{\mathrm{T} 1}$ without any organic compost produced less leaves fresh weight/plant with all media, while it gave heaviest values of leaves fresh weight/plant as 87.89 and 112.68 from using $\mathrm{OC}_{\mathrm{T} 5}$ and peat moss, in the two seasons, respectively, as compared to the other media. Concerning pot media, peat moss showed better leaves fresh weight. The favorable effect of peat moss was mainly due to its higher organic matter content and lower $\mathrm{pH}$ value and electrical conductivity EC, and enhancing the accumulation of biosynthesis and for increasing the fresh weight of leaves.
Table 7. Effect of different media, organic compost and their interaction on the leaves fresh weight/plant (g) of Gazania splendens during 2017 and 2018 seasons.

\begin{tabular}{|c|c|c|c|c|}
\hline \multirow{2}{*}{$\begin{array}{l}\text { Organic } \\
\text { compost } \\
\text { treatments } \\
\text { (B) } \\
\end{array}$} & \multicolumn{3}{|c|}{ Media (A) } & \multirow[b]{2}{*}{$\begin{array}{c}\text { Mean } \\
\text { (B) }\end{array}$} \\
\hline & Sandy & Calcareous & $\begin{array}{l}\text { Peat } \\
\text { moss }\end{array}$ & \\
\hline & \multicolumn{4}{|c|}{ First season } \\
\hline $\mathrm{OC}_{\mathrm{T} 1}$ & 35.88 & 35.40 & 19.10 & 30.13 \\
\hline $\mathrm{OC}_{\mathrm{T} 2}$ & 36.36 & 40.58 & 48.20 & 41.71 \\
\hline $\mathrm{OC}_{\mathrm{T} 3}$ & 65.05 & 62.58 & 54.12 & 60.58 \\
\hline $\mathrm{OC}_{\mathrm{T} 4}$ & 53.31 & 66.22 & 61.93 & 60.49 \\
\hline $\mathrm{OC}_{\mathrm{T} 5}$ & 66.60 & 70.21 & 87.89 & 74.89 \\
\hline Mean (A) & 51.44 & 54.99 & 54.25 & \\
\hline \multirow[t]{2}{*}{$\underline{\text { LSD }_{0.05}}$} & \multicolumn{4}{|c|}{$\mathrm{A}=1.86 \mathrm{~B}=3.23 \mathrm{~A} \times \mathrm{B}=5.60$} \\
\hline & \multicolumn{4}{|c|}{ Second season } \\
\hline $\mathrm{OC}_{\mathrm{T} 1}$ & 46.00 & 45.39 & 24.49 & 38.63 \\
\hline $\mathrm{OC}_{\mathrm{T} 2}$ & 46.62 & 52.02 & 61.80 & 53.48 \\
\hline $\mathrm{OC}_{\mathrm{T} 3}$ & 83.40 & 80.23 & 69.39 & 77.67 \\
\hline $\mathrm{OC}_{\mathrm{T} 4}$ & 63.34 & 84.90 & 79.40 & 77.55 \\
\hline $\mathrm{OC}_{\mathrm{T} 5}$ & 85.38 & 90.01 & 112.68 & 96.02 \\
\hline Mean (A) & 65.95 & 70.51 & 69.55 & \\
\hline LSD $_{0.05}$ & $A=$ & $.38 \quad \mathrm{~B}=4.14$ & $\mathrm{~A} \times \mathrm{B}=7.1$ & \\
\hline
\end{tabular}

These results were in harmony with, Soliman (2005) on Lawsonia alba, Lam. and Hendawy et al. (2015) on Plantago arenaria.

\section{Leaves dry weight/plant (g):}

Data presented in Table (8) showed that media had insignificant effects on that trait, while compost treatments and the interaction between different media and compost treatments had significant effect on leaves dry weight/plant (g) in the two seasons of study. With regard to different media, peat moss and sandy gave the heavier leaves dry weight, though insignificant, than calcareous in both seasons. Organic compost at $60 \%$ sugar beet compost, $60 \%$ rice straw and $30 \%$ sugar beet compost gave statistically the highest values for leaves dry weight/plant in both seasons. For the interaction, organic compost responded significantly and differently to media. $\mathrm{OC}_{\mathrm{T} 3}$ showed significant response to media type which gave higher value in peat moss and calcareous media as compared to sandy soil. Meanwhile, $\mathrm{OC}_{\mathrm{T} 4}$ had significantly lower value in calcareous and sandy media, while it 
Table 8. Effect of different media, organic compost and their interaction on the leaves dry weight/plant (g) of Gazania splendens during 2017 and 2018 seasons.

\begin{tabular}{|c|c|c|c|c|}
\hline \multirow{2}{*}{$\begin{array}{l}\text { Organic } \\
\text { compost } \\
\text { treatments } \\
\text { (B) }\end{array}$} & \multicolumn{3}{|c|}{ Media (A) } & \multirow[b]{2}{*}{$\begin{array}{l}\text { Mean } \\
\text { (B) }\end{array}$} \\
\hline & Sandy & Calcareous & $\begin{array}{l}\text { Peat } \\
\text { moss }\end{array}$ & \\
\hline & \multicolumn{4}{|c|}{ First season } \\
\hline $\mathrm{OC}_{\mathrm{T} 1}$ & 11.47 & 10.60 & 7.02 & 9.69 \\
\hline OC & 11.32 & 11.91 & 12.07 & 11.76 \\
\hline ОСтз & 13.91 & 15.07 & 16.71 & 15.23 \\
\hline $\mathrm{OC}_{\mathrm{T} 4}$ & 14.91 & 14.41 & 15.89 & 15.07 \\
\hline $\mathrm{OC}_{\mathrm{T} 5}$ & 15.78 & 14.03 & 17.88 & 15.90 \\
\hline Mean (A) & 13.48 & 13.20 & 13.91 & \\
\hline \multirow[t]{2}{*}{$\underline{L S D}_{0.05}$} & $A=N . S$ & $5 \quad B=1.69$ & $\mathrm{~A} \times \mathrm{B}=2.9$ & \\
\hline & \multicolumn{4}{|c|}{ Second season } \\
\hline $\mathrm{OC}_{\mathrm{T} 1}$ & 14.70 & 13.59 & 9.00 & 12.43 \\
\hline OC & 14.51 & 15.27 & 15.47 & 15.08 \\
\hline ОС тз & 17.83 & 19.32 & 21.42 & 19.53 \\
\hline ОСт4 & 19.12 & 18.48 & 20.37 & 19.32 \\
\hline $\mathrm{OC}_{\mathrm{T} 5}$ & 20.23 & 17.99 & 22.93 & 20.39 \\
\hline Mean (A) & 17.28 & 16.93 & 17.84 & \\
\hline LSD $_{0.05}$ & $A=N . S$ & $S \quad B=2.17$ & $\mathrm{~A} \times \mathrm{B}=3.77$ & \\
\hline
\end{tabular}

* N.S: not significant.

gave significantly higher value in peat moss, in the two seasons. $\mathrm{OC}_{\mathrm{TI}}$ gave less heavy leaves dry weight in peat moss medium without any organic compost compared to calcareous and sandy media, as it reached only 7.02 and 9.00 , in the two seasons, respectively. The highest values were obtained using $\mathrm{OC}_{\mathrm{T} 5}$ with peat moss and sandy soil, in the two seasons. This increase in leaves dry weight may be due to increment in number of leaves and leaf area. These results were in harmony with Algur and Kadioğlu (1992) on Helianthus annus, and Youssef (2008) on Pelargonium zonale.

\section{Flowering characteristics:}

\section{Inflorescence diameter $(\mathbf{c m})$ :}

Results presented in Table (9) indicated that inflorescences diameter gave the significantly highest value of 8.65 and 8.29 $\mathrm{cm}$ for peat moss in September in both seasons, respectively. On the other hand, the lowest values were recorded in calcareous soil $(4.76 \mathrm{~cm}$ in August 2017and $6.01 \mathrm{~cm}$ in November 2018). The treatment of $\mathrm{OC}_{\mathrm{T} 5}$ (60\% sugar beet) gave the significantly highest values of 8.84 and $8.82 \mathrm{~cm}$ in September 2017 and 2018 respectively, while the lowest values were recorded for control (4.68 cm in August 2017 and 5.91 $\mathrm{cm}$ in November 2018), Table (10). Means of inflorescence diameter as affected by growing media and organic compost treatments, in the two seasons, are presented in Table (11) The results indicated that $\mathrm{OC}_{\mathrm{T} 4}$ showed fairly constant response to the three growing media in all months, whereas all other compost treatments showed significantly higher values of inflorescence diameter in peat moss media than sandy or calcareous media. The highest value, in all months, was obtained with $\mathrm{OC}_{\mathrm{T} 5}$ at peat moss medium, whereas the lowest values were recorded for $\mathrm{OC}_{\mathrm{T} 1}$ in calcareous media. These results may be related to the presence of compost at a suitable ratio which led to improve the soil characters and provide the plants with minerals, consequently the vegetative growth parameters of the used plants would be increased and thus their flower quality was improved. Many researches obtained similar results such as EL-Sayed (1991) on Chrysanthemum and Dianthus, Abdul-Hafeez et al. (2015) on Gardenia jasminoides, and Idrovo et al. (2019) on Rosa hybrida.

\section{Number of inflorescences/plant:}

Number of inflorescences/plant was higher in peat moss, significantly or insignificantly, in all months except October where calcareous medium gave significantly higher values Table (12). Concerning organic compost treatments Table (13), OCT5 and $\mathrm{OC}_{\mathrm{T} 4}$ gave higher number of inflorescences/plant in all months, except in October where $\mathrm{OC}_{\mathrm{T} 3}$ produced the highest value for that trait in the two seasons. With regard to compost treatment and media interaction, data in Table (14) indicated that the interaction between the two studied factors varied with the month. In June, OC ${ }_{T 1}$ gave stable response to all three media, and the highest value for number of inflorescences/plant was obtained with $\mathrm{OC}_{\mathrm{T} 5}$ and peat moss media. 
A.H. El-Naggar et al.

Table 9. Effect of different media on inflorescences diameter $(\mathrm{cm})$ of Gazania splendens during 2017 and 2018 seasons.

\begin{tabular}{lcccccccccccc}
\hline \multirow{2}{*}{ Media } & \multicolumn{2}{c}{ June } & \multicolumn{2}{c}{ July } & \multicolumn{2}{c}{ August } & \multicolumn{3}{c}{ September } & \multicolumn{2}{c}{ October } & \multicolumn{2}{c}{ November } \\
& $\mathbf{2 0 1 7}$ & $\mathbf{2 0 1 8}$ & $\mathbf{2 0 1 7}$ & $\mathbf{2 0 1 8}$ & $\mathbf{2 0 1 7}$ & $\mathbf{2 0 1 8}$ & $\mathbf{2 0 1 7}$ & $\mathbf{2 0 1 8}$ & $\mathbf{2 0 1 7}$ & $\mathbf{2 0 1 8}$ & $\mathbf{2 0 1 7}$ & $\mathbf{2 0 1 8}$ \\
\hline Sand & 6.53 & 7.25 & 5.80 & 6.90 & 5.07 & 6.66 & 7.97 & 7.74 & 6.89 & 6.87 & 6.16 & 6.46 \\
Calcareous & 6.12 & 6.80 & 5.44 & 6.45 & 4.76 & 6.36 & 7.48 & 7.36 & 6.46 & 6.51 & 5.78 & 6.01 \\
Peat moss & 7.08 & 7.86 & 6.29 & 7.51 & 5.50 & 6.96 & 8.65 & 8.29 & 7.47 & 7.72 & 6.68 & 7.07 \\
L.S.D 0.05 & 0.394 & 0.439 & 0.351 & 0.439 & 0.307 & 0.359 & 0.483 & 0.440 & 0.417 & 0.317 & 0.373 & 0.439 \\
\hline
\end{tabular}

Table 10. Effect of organic compost on inflorescences diameter (cm) of Gazania splendens during 2017 and 2018 seasons.

\begin{tabular}{|c|c|c|c|c|c|c|c|c|c|c|c|c|}
\hline \multirow{2}{*}{$\begin{array}{l}\text { Organic } \\
\text { compost } \\
\text { Treatments }\end{array}$} & \multicolumn{2}{|c|}{ June } & \multicolumn{2}{|c|}{ July } & \multicolumn{2}{|c|}{ August } & \multicolumn{2}{|c|}{ September } & \multicolumn{2}{|c|}{ October } & \multicolumn{2}{|c|}{ November } \\
\hline & 2017 & 2018 & 2017 & 2018 & 2017 & 2018 & 2017 & 2018 & 2017 & 2018 & 2017 & 2018 \\
\hline $\mathrm{OC}_{\mathrm{T} 1}$ & 6.02 & 6.69 & 5.35 & 6.35 & 4.68 & 6.35 & 7.36 & 7.37 & 6.36 & 6.71 & 5.69 & 5.91 \\
\hline $\mathrm{OC}_{\mathrm{T} 2}$ & 6.35 & 7.06 & 5.64 & 6.71 & 4.94 & 6.37 & 7.76 & 7.37 & 6.70 & 6.63 & 6.00 & 6.27 \\
\hline OC $_{\text {T3 }}$ & 6.33 & 7.03 & 5.63 & 6.68 & 4.92 & 6.38 & 7.74 & 7.30 & 6.68 & 6.83 & 5.98 & 6.25 \\
\hline $\mathrm{OC}_{\mathrm{T} 4}$ & 6.91 & 7.68 & 6.14 & 7.33 & 5.38 & 6.85 & 8.45 & 8.11 & 7.30 & 7.09 & 6.53 & 6.89 \\
\hline $\mathrm{OC}_{\mathrm{T} 5}$ & 7.24 & 8.04 & 6.44 & 7.69 & 5.63 & 7.37 & 8.84 & 8.82 & 7.64 & 7.91 & 6.84 & 7.26 \\
\hline L.S.D.D 0.05 & 0.228 & 0.254 & 0.203 & 0.254 & 0.177 & 0.255 & 0.279 & 0.260 & 0.241 & 0.399 & 0.215 & 0.254 \\
\hline
\end{tabular}

Table 11. Effect of different media, organic compost and their interaction on inflorescences diameter $(\mathrm{cm})$ of Gazania splendens during 2017 and 2018 seasons.

\begin{tabular}{|c|c|c|c|c|c|c|c|c|c|c|c|c|}
\hline \multirow{3}{*}{ Interaction } & \multicolumn{12}{|c|}{ Inflorescences diameter (cm) } \\
\hline & \multicolumn{2}{|c|}{ June } & \multicolumn{2}{|c|}{ July } & \multicolumn{2}{|c|}{ August } & \multicolumn{2}{|c|}{ September } & \multicolumn{2}{|c|}{ October } & \multicolumn{2}{|c|}{ November } \\
\hline & 2017 & 2018 & 2017 & 2018 & 2017 & 2018 & 2017 & 2018 & 2017 & 2018 & 2017 & 2018 \\
\hline $\mathbf{M}_{1} * \mathbf{O C}_{\mathrm{T} 1}$ & 6.03 & 6.70 & 5.36 & 6.35 & 4.69 & 6.08 & 7.30 & 7.21 & 6.36 & 6.47 & 5.69 & 5.91 \\
\hline $\mathbf{M}_{1} * \mathrm{OC}_{\mathrm{T} 2}$ & 6.54 & 7.27 & 5.82 & 6.92 & 5.09 & 6.59 & 8.00 & 7.66 & 6.91 & 6.67 & 6.18 & 6.48 \\
\hline $\mathbf{M}_{1} * \mathrm{OC}_{\mathrm{T} 3}$ & 6.34 & 7.04 & 5.63 & 6.69 & 4.92 & 6.36 & 7.74 & 7.30 & 6.69 & 6.65 & 5.98 & 6.25 \\
\hline $\mathrm{M}_{1} * \mathrm{OC}_{\mathrm{T} 4}$ & 6.96 & 7.73 & 6.18 & 7.38 & 5.41 & 7.10 & 8.50 & 7.93 & 7.34 & 7.08 & 6.57 & 6.94 \\
\hline $\mathbf{M}_{1} * \mathbf{O C}_{\mathrm{T} 5}$ & 6.75 & 7.50 & 6.00 & 7.15 & 5.25 & 7.17 & 8.25 & 8.58 & 7.12 & 7.49 & 6.37 & 6.71 \\
\hline $\mathbf{M}_{2} * \mathrm{OC}_{\mathrm{T} 1}$ & 4.80 & 5.33 & 4.26 & 4.98 & 3.73 & 5.83 & 5.86 & 6.39 & 5.06 & 5.95 & 4.53 & 4.54 \\
\hline $\mathbf{M}_{2} * \mathrm{OC}_{\mathrm{T} 2}$ & 5.78 & 6.43 & 5.14 & 6.08 & 4.50 & 6.07 & 7.07 & 6.78 & 6.10 & 5.76 & 5.46 & 5.64 \\
\hline $\mathbf{M}_{2} * \mathrm{OC}_{\mathrm{T} 3}$ & 5.98 & 6.64 & 5.31 & 6.29 & 4.65 & 6.08 & 7.30 & 6.94 & 6.31 & 6.53 & 5.64 & 5.85 \\
\hline $\mathbf{M}_{2} * \mathrm{OC}_{\mathrm{T} 4}$ & 6.85 & 7.61 & 6.09 & 7.26 & 5.32 & 6.65 & 8.37 & 7.99 & 7.23 & 6.58 & 6.47 & 6.82 \\
\hline $\mathbf{M}_{2} * \mathbf{O C}_{\mathrm{T} 5}$ & 7.19 & 7.99 & 6.39 & 7.64 & 5.59 & 7.19 & 8.79 & 8.69 & 7.59 & 7.72 & 6.79 & 7.20 \\
\hline $\mathrm{M}_{3} * \mathrm{OC}_{\mathrm{T} 1}$ & 7.25 & 8.05 & 6.44 & 7.70 & 5.63 & 7.13 & 8.85 & 8.51 & 7.64 & 7.70 & 6.84 & 7.26 \\
\hline $\mathbf{M}_{3} * \mathrm{OC}_{\mathrm{T} 2}$ & 6.70 & 7.47 & 5.98 & 7.12 & 5.23 & 6.45 & 8.22 & 7.66 & 7.10 & 7.45 & 6.35 & 6.68 \\
\hline $\mathbf{M}_{3} * \mathrm{OC}_{\mathrm{T} 3}$ & 6.68 & 7.42 & 5.94 & 7.07 & 5.19 & 6.68 & 8.17 & 7.66 & 7.05 & 7.30 & 6.31 & 6.63 \\
\hline $\mathbf{M}_{3} * \mathrm{OC}_{\mathrm{T} 4}$ & 6.94 & 7.71 & 6.17 & 7.36 & 5.39 & 6.79 & 8.48 & 8.42 & 7.32 & 7.60 & 6.55 & 6.92 \\
\hline $\mathbf{M}_{3} * \mathrm{OC}_{\mathrm{T} 5}$ & 7.77 & 8.64 & 6.91 & 8.29 & 6.04 & 7.76 & 9.50 & 9.18 & 8.20 & 8.53 & 7.34 & 7.85 \\
\hline $\mathbf{L S D}_{0.05}$ & 0.39 & 0.44 & 0.35 & 0.44 & 0.31 & 0.44 & 0.48 & 0.44 & 0.41 & 0.69 & 0.37 & 0.44 \\
\hline
\end{tabular}


Table 12. Effect of different media on number of inflorescences/plant of Gazania splendens during 2017 and 2018 seasons.

\begin{tabular}{|c|c|c|c|c|c|c|c|c|c|c|c|c|}
\hline \multirow{2}{*}{ Media } & \multicolumn{2}{|c|}{ June } & \multicolumn{2}{|c|}{ July } & \multicolumn{2}{|c|}{ August } & \multicolumn{2}{|c|}{ September } & \multicolumn{2}{|c|}{ October } & \multicolumn{2}{|c|}{ November } \\
\hline & 2017 & 2018 & 2017 & 2018 & 2017 & 2018 & 2017 & 2018 & 2017 & 2018 & 2017 & 2018 \\
\hline Sand & 1.58 & 1.21 & 2.17 & 1.86 & 1.99 & 1.58 & 1.70 & 1.32 & 1.32 & 1.09 & 2.70 & 1.60 \\
\hline Calcareous & 1.96 & 1.56 & 2.27 & 1.92 & 2.43 & 2.09 & 1.97 & 1.72 & 1.84 & 1.65 & 1.95 & 1.36 \\
\hline Peat moss & 2.43 & 1.98 & 2.41 & 1.95 & 2.24 & 1.91 & 1.82 & 1.50 & 1.49 & 1.32 & 3.25 & 1.77 \\
\hline L.S.D 0.05 & 0.25 & 0.21 & N.S & N.S & 0.33 & 0.38 & N.S & N.S & 0.24 & 0.22 & 0.43 & 0.14 \\
\hline
\end{tabular}

* N.S: not significant.

Table 13. Effect of organic compost on number of inflorescences/plant of Gazania splendens during 2017 and 2018 seasons.

\begin{tabular}{lcccccccccccc}
\hline Organic compost & \multicolumn{2}{c}{ June } & \multicolumn{1}{c}{ July } & \multicolumn{2}{c}{ August } & \multicolumn{2}{c}{ September } & \multicolumn{2}{c}{ October } & \multicolumn{2}{c}{ November } \\
Treatments & $\mathbf{2 0 1 7}$ & $\mathbf{2 0 1 8}$ & $\mathbf{2 0 1 7}$ & $\mathbf{2 0 1 8}$ & $\mathbf{2 0 1 7}$ & $\mathbf{2 0 1 8}$ & $\mathbf{2 0 1 7}$ & $\mathbf{2 0 1 8}$ & $\mathbf{2 0 1 7}$ & $\mathbf{2 0 1 8}$ & $\mathbf{2 0 1 7}$ & $\mathbf{2 0 1 8}$ \\
\hline OC $_{\text {T1 }}$ & 1.68 & 1.33 & 1.98 & 1.71 & 1.75 & 1.55 & 1.74 & 1.44 & 1.30 & 1.14 & 1.41 & 1.19 \\
OC $_{\text {T2 }}$ & 1.78 & 1.42 & 2.04 & 1.74 & 2.03 & 1.57 & 1.67 & 1.31 & 1.47 & 1.24 & 1.83 & 1.32 \\
OC $_{\text {T3 }}$ & 1.84 & 1.45 & 2.31 & 1.94 & 2.46 & 2.07 & 1.95 & 1.62 & 1.82 & 1.60 & 2.58 & 1.57 \\
OC $_{\text {T4 }}$ & 2.27 & 1.78 & 2.40 & 1.97 & 2.34 & 1.94 & 1.88 & 1.53 & 1.58 & 1.38 & 3.50 & 1.85 \\
OC $_{\text {T5 }}$ & 2.36 & 1.94 & 2.68 & 2.20 & 2.52 & 2.17 & 1.94 & 1.67 & 1.60 & 1.41 & 3.83 & 1.93 \\
L.S.D.05 & 0.40 & 0.40 & 0.37 & N.S & 0.34 & 0.35 & N.S & N.S & 0.26 & 0.24 & 0.62 & 0.20 \\
\hline
\end{tabular}

* N.S: not significant.

Table 14. Effect of different media, organic compost and their interaction on number of inflorescences/ plant of Gazania splendens during 2017 and 2018 seasons.

\begin{tabular}{|c|c|c|c|c|c|c|c|c|c|c|c|c|}
\hline \multirow{3}{*}{ Interaction } & \multicolumn{12}{|c|}{ Inflorescences diameter (cm) } \\
\hline & \multicolumn{2}{|c|}{ June } & \multicolumn{2}{|c|}{ July } & \multicolumn{2}{|c|}{ August } & \multicolumn{2}{|c|}{ September } & \multicolumn{2}{|c|}{ October } & \multicolumn{2}{|c|}{ November } \\
\hline & 2017 & 2018 & 017 & 2018 & 017 & 2018 & 2017 & 2018 & 2017 & 2018 & 2017 & 2018 \\
\hline & & & & & & & & & 40 & & .50 & 1.23 \\
\hline & 1.26 & & & 1.79 & & 1.21 & & & 09 & 70 & 50 & 1.20 \\
\hline $\mathbf{M}_{1} * \mathbf{O C}_{\mathbf{T} 3}$ & 1.18 & 0.83 & 2.03 & 1.69 & 94 & 1.50 & 1.83 & 1.41 & 1.53 & 1.38 & 2.75 & 1.65 \\
\hline $\mathbf{M}_{1} * \mathbf{O C}_{\mathrm{T} 4}$ & 1.49 & 100 & 1.92 & $\therefore$ & 6 & 1 & 1.50 & 1.06 & 18 & 18 & 3.50 & 1.86 \\
\hline & 2.18 & & & & & & & & & & & 2.05 \\
\hline $\mathbf{M}_{2} * \mathbf{O C}_{\mathrm{T} 1}$ & 1.79 & 1.49 & 2.10 & 1.92 & 1.94 & 1.98 & 1.98 & 1.71 & 1.40 & 1.27 & 1.00 & 1.02 \\
\hline $\mathbf{M}_{2} * \mathbf{O C}_{\mathbf{T} 2}$ & 1.82 & 1.48 & 2.10 & 1.69 & 2.39 & 1.70 & 1.97 & 1.69 & 1.90 & 1.78 & 1.50 & 1.20 \\
\hline $\mathbf{M}_{2} * \mathbf{O C}_{\mathbf{T} 3}$ & 1.73 & 1.4 & 2.30 & 1.90 & 2.65 & 2.25 & 1.92 & 1 & 5 & 1.78 & 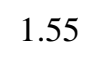 & 1.20 \\
\hline $\mathbf{M}_{2} * \mathrm{OC}_{\mathrm{T} 4}$ & 2.48 & & & & & & & & 2.16 & & 0.00 & \\
\hline $\mathbf{M}_{2} * \mathbf{O C}_{\mathbf{T 5}}$ & 1.97 & & & & & & & & 1.69 & & 2.75 & \\
\hline $\mathbf{M}_{3} * \mathrm{OC}_{\mathrm{T} 1}$ & 1.47 & 1.05 & 1.67 & 1.38 & 1.27 & 0.96 & 1.37 & 1.18 & 1.09 & 1.18 & 1.75 & 1.31 \\
\hline $\mathbf{M}_{3} * \mathbf{O C}_{\mathrm{T} 2}$ & 2.27 & 1.86 & & & & & & & 1.40 & 22 & 2.50 & 1.57 \\
\hline $\mathbf{M}_{3} * \mathbf{O C}_{\mathbf{T} 3}$ & 2.62 & 2.11 & 2.60 & 2.20 & & 2.43 & 2.09 & 1.62 & 1.87 & 1.62 & 3.50 & 1.86 \\
\hline $\mathbf{M}_{3} * \mathrm{OC}_{\mathrm{T} 4}$ & 2.84 & 2.34 & 2.53 & 1.97 & 2.26 & 1.91 & 1.72 & 1.09 & 1.40 & 1.09 & 4.00 & 1.99 \\
\hline $\mathbf{M}_{3} * \mathbf{O C}_{\mathbf{T} 5}$ & 2.93 & 2.50 & 3.14 & 2.48 & 2.76 & 2.42 & 2.26 & 1.47 & 1.69 & 1.47 & 4.50 & 2.11 \\
\hline LSD $_{0.05}$ & 0.70 & 0.69 & 0.64 & N.S & N.S & 0.61 & 0.54 & 0.58 & N.S & N.S & N.S & N.S \\
\hline
\end{tabular}

* N.S: not significant. 


\section{A.H. El-Naggar et al.}

However, in September, the highest value for that trait was obtained from $\mathrm{OC}_{\mathrm{T} 4}$ with calcareous medium. Perner et al. (2007) proposed that this effect was due to the higher water holding capacity of peat mossbased substrates with higher compost addition rate. Previous researches reported similar variability in number of inflorescences between different treatments El-Nagger and El-Nasharty (2009) on Hippeastrum vittatum, Soliman et al. (2013) on Gardenia Jasminoides and Abdul-Hafeez et al. (2015) on Gardenia jasminoides.

\section{Inflorescence dry weights (g):}

Dry weight of inflorescence Table (15), showed variable response to media in the two seasons. In the first season, sandy and peat moss media showed statistically comparable values for that character, whereas, in July, August and September 2018, peat moss was significantly superior to sandy and calcareous media for that character. With regard to the effect of compost treatment, the means presented in Table (16) showed that $\mathrm{OC}_{\mathrm{T} 1}$ gave the significantly lowest dry weight of inflorescence in all months of the two seasons of study. Treatments of $\mathrm{OC}_{\mathrm{T} 2}$ and $\mathrm{OC}_{\mathrm{T} 3}$ were similar in their effect on inflorescence dry weight and significantly higher than $\mathrm{OC}_{\mathrm{T} 1}$. OC ${ }_{\mathrm{T} 5}$ which was60\% sugar beet compost gave significantly heavier inflorescences than $\mathrm{OC}_{\mathrm{T}}$ in all months of the two seasons. The interaction between organic compost and media Table (17) varied with the season and month of inflorescence dry weight determination. In June $\mathrm{OC}_{\mathrm{T} 2}$ and $\mathrm{OC}_{\mathrm{T} 3}$ gave statistically similar response using the three media. $\mathrm{OC}_{\mathrm{T} 4}$ was superior in sandy medium, whereas both gave comparable means in calcareous and peat moss media. $\mathrm{OC}_{\mathrm{T} 1}$ gave heaviest inflorescences with peat moss compared to calcareous; $\mathrm{OC}_{\mathrm{T} 2}$ in sandy and peat moss media were superior to calcareous medium and $\mathrm{OC}_{\mathrm{T} 3}$ in peat moss was superior to both calcareous and sandy media. This result could be attributed to the high organic matter content of peat, which increases the microorganism's activity in the medium. These results of the study are in agreement with those of Atta-Alla et al. (2003) on Gladiolus antakiensis, Sherif and EL-Naggar (2005) on Zantedeschia aethiopica, and Mousa et al. (2015) on Gardenia jaminoides.

\section{Chemical analysis:}

\section{Chlorophyll content in the leaves (SPAD unit):}

Data presented in Table (18) showed that different media, compost treatments and their interactions had significant effects on that trait in the two seasons of study for chlorophyll content in leaves. With regard to different media, results presented in Table (18) showed that peat moss and calcareous media gave higher values of 45.22,56.52 and $45.10,56.37$, respectively in the two summer seasons. Means of compost treatments effect Table (18) showed that organic compost at $60 \%$ sugar beet produced the highest chlorophyll content of 46.92 and 58.65 SPAD respectively, while the lowest values resulted from the treatment without any organic compost 41.57 and 51.96 SPAD in both seasons, respectively. For the interaction effect on that character, means presented in Table (18) showed that organic compost treatments gave different values with the media used. $\mathrm{OC}_{\mathrm{T} 3}$ gave statistically similar values in peat moss and calcareous media, while it gave lowest value with sandy medium. $\mathrm{OC}_{\mathrm{T} 4}$ had significantly high value in calcareous medium of 48.68 and 60.85 SPAD compared to sandy and peat moss media. Meanwhile, $\mathrm{OC}_{\mathrm{T} 5}$ gave significantly higher value of chlorophyll content with peat moss 49.98 and 62.48 SPAD, respectively. In the both seasons, such increase in photosynthetic pigments formation could be attributed to the difference in their composition. Similar results were noticed by other residues, Youssef (2008) with Pentas laneceolata, El-Naggar and El-Nasharty (2009) on Hippeastrum vittatum,

\section{Nitrogen in the leaves (\%):}

Data presented in Table (19) showed that different media and compost treatment had 
Table 15. Effect of different media on number of inflorescences/plant of Gazania splendens during 2017 and 2018 seasons.

\begin{tabular}{lcccccccccccc}
\hline \multirow{2}{*}{ Media } & \multicolumn{2}{c}{ June } & \multicolumn{2}{c}{ July } & \multicolumn{2}{c}{ August } & \multicolumn{2}{c}{ September } & \multicolumn{2}{c}{ October } & \multicolumn{2}{c}{ November } \\
& $\mathbf{2 0 1 7}$ & $\mathbf{2 0 1 8}$ & $\mathbf{2 0 1 7}$ & $\mathbf{2 0 1 8}$ & $\mathbf{2 0 1 7}$ & $\mathbf{2 0 1 8}$ & $\mathbf{2 0 1 7}$ & $\mathbf{2 0 1 8}$ & $\mathbf{2 0 1 7}$ & $\mathbf{2 0 1 8}$ & $\mathbf{2 0 1 7}$ & $\mathbf{2 0 1 8}$ \\
\hline Sand & 0.293 & 0.345 & 0.258 & 0.290 & 0.224 & 0.261 & 0.189 & 0.258 & 0.362 & 0.402 & 0.396 & 0.434 \\
Calcareous & 0.249 & 0.294 & 0.220 & 0.275 & 0.191 & 0.259 & 0.161 & 0.256 & 0.308 & 0.314 & 0.338 & 0.382 \\
Peat moss & 0.295 & 0.348 & 0.261 & 0.386 & 0.226 & 0.376 & 0.191 & 0.380 & 0.365 & 0.417 & 0.400 & 0.409 \\
L.S.D & 0.0137 & 0.0161 & 0.012 & 0.023 & 0.0104 & 0.022 & 0.0088 & 0.0193 & 0.0169 & 0.0109 & 0.0185 & 0.0154 \\
\hline
\end{tabular}

Table 16. Effect of organic compost on inflorescences dry weight (g) of Gazania splendens during 2017 and 2018 seasons.

\begin{tabular}{|c|c|c|c|c|c|c|c|c|c|c|c|c|}
\hline \multirow{2}{*}{$\begin{array}{l}\text { Organic } \\
\text { compost } \\
\text { Treatments }\end{array}$} & \multicolumn{2}{|c|}{ June } & \multicolumn{2}{|c|}{ July } & \multicolumn{2}{|c|}{ August } & \multicolumn{2}{|c|}{ September } & \multicolumn{2}{|c|}{ October } & \multicolumn{2}{|c|}{ November } \\
\hline & 2017 & 2018 & 2017 & 2018 & 2017 & 2018 & 2017 & 2018 & 017 & 2018 & 2017 & 2018 \\
\hline $\mathrm{OC}_{\mathrm{T} 1}$ & 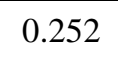 & & 0.222 & 0 . & 0.192 & & & & 311 & & 0.341 & 378 \\
\hline $\mathrm{OC}_{\mathrm{T} 2}$ & .264 & & 0.233 & 0.314 & 0.202 & 0.294 & 0.171 & 0.287 & 0.327 & 0.356 & 0.358 & 0.391 \\
\hline $\mathrm{OC}_{\mathrm{T} 3}$ & 9 & 0.3 & 7 & 0 & $\angle 0 J$ & O & 4 & 6 & 32 & 7 & 4 & 396 \\
\hline $\mathrm{OC}_{\mathrm{T} 4}$ & 38 & 0.339 & 0.254 & 0. & 0.220 & 6 & 36 & 2 & 26 & 39 & 0.390 & 0.419 \\
\hline $\mathrm{OC}_{\mathrm{T} 5}$ & 23 & 0.380 & 0.285 & 0. & 0.247 & 3 & 0.209 & 43 & 0.399 & 0.432 & 0.437 & 0.460 \\
\hline L.S.Do & 155 & 0.0183 & 0.0137 & 0.022 & 0.0119 & 0.0212 & 0.0101 & 0.0169 & 0.0192 & 0.0188 & 0.0210 & 0.0186 \\
\hline
\end{tabular}

Table 17. Effect of different media, organic compost and their interaction on inflorescences dry weight (g) of Gazania splendens during 2017 and 2018 seasons.

\begin{tabular}{|c|c|c|c|c|c|c|c|c|c|c|c|c|}
\hline \multirow{3}{*}{ Interaction } & \multicolumn{12}{|c|}{ Inflorescences diameter (cm) } \\
\hline & \multicolumn{2}{|c|}{ June } & \multicolumn{2}{|c|}{ July } & \multicolumn{2}{|c|}{ August } & \multicolumn{2}{|c|}{ September } & \multicolumn{2}{|c|}{ October } & \multicolumn{2}{|c|}{ November } \\
\hline & 2017 & 2018 & 2017 & 2018 & 2017 & 2018 & 2017 & 2018 & 2017 & 2018 & 2017 & 2018 \\
\hline $\mathrm{M}_{1} * \mathrm{OC}_{\mathrm{T} 1}$ & 0.238 & 0.280 & 0.210 & 0.271 & 0.182 & 0.242 & 0.154 & 0.240 & 0.294 & 0.337 & 0.322 & 0.369 \\
\hline $\mathbf{M}_{1} * \mathrm{OC}_{\mathrm{T} 2}$ & 0.284 & 0.335 & 0.251 & 0.322 & 0.217 & 0.293 & 0.184 & 0.291 & 0.351 & 0.377 & 0.385 & 0.424 \\
\hline $\mathbf{M}_{1} * \mathrm{OC}_{\mathrm{T} 3}$ & 0.301 & 0.355 & 0.266 & 0.300 & 0.230 & 0.271 & 0.195 & 0.268 & 0.372 & 0.415 & 0.408 & 0.444 \\
\hline $\mathbf{M}_{1} * \mathrm{OC}_{\mathrm{T} 4}$ & 0.318 & 0.375 & 0.281 & 0.276 & 0.243 & 0.247 & 0.206 & 0.244 & 0.393 & & 0.431 & 0.464 \\
\hline $\mathbf{M}_{1} * \mathbf{O C}_{\mathrm{T} 5}$ & 0.323 & 0.380 & 0.285 & 0.281 & 0.247 & & 0.209 & 0.249 & 0.399 & & & 0.469 \\
\hline $\mathbf{M}_{2} * \mathrm{OC}_{\mathrm{T} 1}$ & 0.223 & 0.262 & 0.196 & 0.243 & 0.170 & 0.222 & 0.144 & 0.219 & 0.275 & 0.282 & 0.301 & 0.351 \\
\hline $\mathbf{M}_{2} * \mathrm{OC}_{\mathrm{T} 2}$ & 0.225 & 0.365 & 0.198 & 0.246 & 0.172 & 0.226 & 0.145 & 0.223 & 0.278 & 0.285 & 0.304 & 0.353 \\
\hline $\mathbf{M}_{2} * \mathrm{OC}_{\mathrm{T} 3}$ & 0.218 & 0.257 & 0.193 & & 0.167 & & 0.141 & 0.222 & 0.270 & 0.280 & 0.296 & 0.346 \\
\hline $\mathbf{M}_{2} * \mathrm{OC}_{\mathrm{T} 4}$ & 0.269 & 0.317 & 0.238 & 0.298 & 0.206 & 0.287 & 0.174 & 0.284 & 0.333 & 0.337 & 0.365 & 0.406 \\
\hline $\mathbf{M}_{2} * \mathbf{O C}_{\mathrm{T} 5}$ & 0.312 & 0.367 & 0.275 & 0.348 & 0.238 & 0.335 & 0.202 & 0.332 & 0.385 & 0.387 & 0.422 & 0.456 \\
\hline $\mathbf{M}_{3} * \mathrm{OC}_{\mathrm{T} 1}$ & 0.295 & 0.347 & 0.260 & 0.386 & 0.225 & 0.376 & & 0.366 & 0.364 & & 0.399 & 0.414 \\
\hline $\mathbf{M}_{3} * \mathrm{OC}_{\mathrm{T} 2}$ & 0.284 & 0.335 & 0.251 & 0.373 & 0.217 & 0.363 & 0.184 & 0.345 & 0.351 & 0.404 & 0.385 & 0.395 \\
\hline $\mathbf{M}_{3} * \mathrm{OC}_{\mathrm{T} 3}$ & 0.286 & 0.337 & 0.253 & 0.376 & 0.219 & 0.366 & 0.185 & 0.369 & 0.354 & 0.407 & 0.388 & 0.397 \\
\hline $\mathbf{M}_{3} * \mathrm{OC}_{\mathrm{T} 4}$ & 0.276 & 0.325 & 0.243 & 0.373 & 0.211 & 0.353 & 0.178 & 0.377 & 0.341 & 0.394 & 0.373 & 0.385 \\
\hline $\mathbf{M}_{3} * \mathrm{OC}_{\mathrm{T} 5}$ & 0.335 & 0.395 & 0.296 & 0.433 & 0.256 & 0.423 & 0.217 & 0.446 & 0.414 & 0.464 & 0.454 & 0.455 \\
\hline $\mathbf{L S D}_{0.05}$ & 0.0268 & 0.031 & 0.0205 & 0.0379 & 0.0202 & 0.0365 & 0.0169 & 0.029 & 0.0332 & 0.0323 & 0.0362 & 0.0321 \\
\hline
\end{tabular}


Table 18. Effect of different media, organic compost and their interaction on the total chlorophyll content (SPAD) in leaves of Gazania splendens during 2017 and 2018 seasons.

\begin{tabular}{|c|c|c|c|c|}
\hline \multirow{2}{*}{$\begin{array}{l}\text { Organic } \\
\text { compost } \\
\text { treatments } \\
\text { (B) }\end{array}$} & \multicolumn{3}{|c|}{ Media (A) } & \multirow[b]{2}{*}{$\begin{array}{c}\text { Mean } \\
\text { (B) }\end{array}$} \\
\hline & Sandy C & Calcareous & $\begin{array}{l}\text { Peat } \\
\text { moss }\end{array}$ & \\
\hline & \multicolumn{4}{|c|}{ First season } \\
\hline OC 1 & 43.98 & 39.16 & 41.55 & 41.57 \\
\hline ОСт2 & 41.78 & 45.66 & 44.33 & 43.93 \\
\hline ОС & 42.96 & 45.30 & 47.46 & 45.24 \\
\hline $\mathrm{OC}_{\mathrm{T} 4}$ & 44.18 & 48.68 & 42.78 & 45.21 \\
\hline $\mathrm{OC}_{\mathrm{T} 5}$ & 44.10 & 46.69 & 49.98 & 46.92 \\
\hline Mean (A) & 43.40 & 45.10 & 45.22 & \\
\hline \multirow[t]{2}{*}{$\underline{\text { LSD }_{0.05}}$} & $A=1.64$ & $44 \mathrm{~B}=1.32$ & $\mathrm{~A} \times \mathrm{B}=$ & 2.30 \\
\hline & \multicolumn{4}{|c|}{ Second season } \\
\hline $\mathrm{OC}_{\mathrm{T} 1}$ & 54.98 & 48.95 & 51.94 & 51.96 \\
\hline $\mathrm{OC}_{\mathrm{T} 2}$ & 52.23 & 57.08 & 55.41 & 54.91 \\
\hline ОС & 53.70 & 56.62 & 59.32 & 56.55 \\
\hline OC 4 & 55.22 & 60.85 & 53.47 & 56.51 \\
\hline $\mathrm{OC}_{\mathrm{T} 5}$ & 55.11 & 58.36 & 62.48 & 58.65 \\
\hline Mean (A) & 54.25 & 56.37 & 56.52 & \\
\hline LSD 0.05 & $A=2.05$ & $5 \quad B=1.65$ & $\mathrm{~A} \times \mathrm{B}=$ & 2.87 \\
\hline
\end{tabular}

Table 19. Effect of different media, organic compost and their interaction on nitrogen in the leaves (\%) of Gazania splendens during 2017 and 2018 seasons.

\begin{tabular}{lcccc}
\hline $\begin{array}{l}\text { Organic } \\
\text { compost } \\
\text { treatments } \\
\text { (B) }\end{array}$ & Sandy & Calcareous & $\begin{array}{c}\text { Peat } \\
\text { moss }\end{array}$ & $\begin{array}{c}\text { Mean } \\
\text { (B) }\end{array}$ \\
\hline \multicolumn{5}{c}{ First season } \\
OC $_{\text {T1 }}$ & 1.89 & 1.69 & 2.05 & 1.88 \\
OC $_{\text {T2 }}$ & 2.16 & 1.99 & 2.23 & 2.13 \\
OC $_{\text {T3 }}$ & 2.11 & 2.17 & 2.28 & 2.19 \\
OC $_{\text {T4 }}$ & 2.28 & 2.31 & 2.44 & 2.34 \\
OC $_{\text {T5 }}$ & 2.49 & 2.48 & 2.71 & 2.56 \\
Mean (A) $_{\text {LSD }}$ & 2.19 & 2.13 & 2.34 \\
\hline & $\mathrm{A}=0.167$ & $\mathrm{~B}=0.136$ & $\mathrm{~A} \times \mathrm{B}=\mathrm{N} . \mathrm{S}$ \\
\hline OC $_{\text {T1 }}$ & \multicolumn{5}{c}{ Second season } \\
OC $_{\text {T2 }}$ & 1.50 & 1.27 & 2.60 & 1.79 \\
OC $_{\text {T3 }}$ & 1.60 & 1.37 & 2.80 & 1.92 \\
OC $_{\text {T4 }}$ & 1.75 & 1.32 & 2.97 & 2.01 \\
OC $_{\text {T5 }}$ & 1.92 & 1.47 & 3.12 & 2.17 \\
Mean (A) $_{\text {LSD }}$ & 2.05 & 1.65 & 3.42 & 2.37 \\
\hline
\end{tabular}

* N.S: not significant. significant effects on that trait in the two seasons of study, while the interactions between media and compost treatments were insignificant in the first season. With regard to the different media, the results presented in Table (19) showed that peat moss and sandy media gave highest nitrogen \% in the leaves values of $2.34,2.98 \%$ and 2.19, $1.76 \%$, in the two seasons, respectively. Means of compost treatments Table (19) indicated that organic compost at $60 \%$ sugar beet produced the highest values of nitrogen in leaves as $2.56,2.37 \%$ in the two seasons, respectively. For the interaction effect on that character, the values shown in Table (19), revealed that organic compost treatments gave significant effect only in the second season. $\mathrm{OC}_{\mathrm{T} 1 \text { gave }}$ low values of nitrogen in the leaves, while the highest value $3.42 \%$ was obtained from using $\mathrm{OC}_{\mathrm{T} 5}$ and peat moss compared to calcareous and sandy soil, in the second season. Organic matters such as compost could improve soil structure, improving root development, providing plant nutrients and enhancing nutrient uptake by plants. The present results were in agreement with those obtained by Youssef et al. (1998) on Ocimum basilicum, Gad (2003) on Schefflera actinophylla, and El-Sayed et al. (2012) on Freesia refracta.

\section{Phosphorus in the leaves (\%):}

Data presented in Table (20) showed that different media, compost treatment and their interactions had significant effects on phosphorus for that trait in the two seasons of study. With regard to different media effect on phosphorus in the leaves during 2017 and 2018 seasons of study data indicated that peat moss gave higher phosphorus \% in the leaves as 0.51 and $0.69 \%$, respectively, in both seasons than sandy and calcareous media. Means of compost treatments indicated that organic compost at $60 \%$ sugar beet produced the highest phosphorus in the leaves (0.57 and $0.77 \%$ ), respectively in the two seasons. With regard to the mean values of phosphorus in the leaves (\%) under the effect of different media and the compost treatment 
Table 20. Effect of different media, organic compost and their interaction on phosphorus in the leaves (\%) of Gazania splendens during 2017 and 2018 seasons.

\begin{tabular}{|c|c|c|c|c|}
\hline \multirow{2}{*}{$\begin{array}{l}\text { Organic } \\
\text { compost } \\
\text { treatments } \\
\text { (B) } \\
\end{array}$} & \multicolumn{3}{|c|}{ Media (A) } & \multirow[b]{2}{*}{$\begin{array}{c}\text { Mean } \\
\text { (B) }\end{array}$} \\
\hline & Sandy C & Calcareous & $\begin{array}{l}\text { Peat } \\
\text { moss }\end{array}$ & \\
\hline & \multicolumn{4}{|c|}{ First season } \\
\hline $\mathrm{OC}_{\mathrm{T} 1}$ & 0.35 & 0.34 & 0.37 & 0.35 \\
\hline $\mathrm{OC}_{\mathrm{T} 2}$ & 0.44 & 0.37 & 0.42 & 0.41 \\
\hline $\mathrm{OC}_{\mathrm{T} 3}$ & 0.47 & 0.37 & 0.54 & 0.46 \\
\hline $\mathrm{OC}_{\mathrm{T} 4}$ & 0.56 & 0.46 & 0.58 & 0.53 \\
\hline $\mathrm{OC}_{\mathrm{T} 5}$ & 0.63 & 0.46 & 0.62 & 0.57 \\
\hline Mean (A) & 0.49 & 0.40 & 0.51 & \\
\hline \multirow[t]{2}{*}{ LSD $_{0.05}$} & $A=0.15$ & $5 \quad \mathrm{~B}=0.02$ & $\mathrm{~A} \times \mathrm{B}=$ & 0.040 \\
\hline & \multicolumn{4}{|c|}{ Second season } \\
\hline $\mathrm{OC}_{\mathrm{T} 1}$ & 0.48 & 0.46 & 0.50 & 0.48 \\
\hline $\mathrm{OC}_{\mathrm{T} 2}$ & 0.59 & 0.51 & 0.57 & 0.56 \\
\hline $\mathrm{OC}_{\mathrm{T} 3}$ & 0.64 & 0.50 & 0.73 & 0.62 \\
\hline $\mathrm{OC}_{\mathrm{T} 4}$ & 0.76 & 0.62 & 0.79 & 0.72 \\
\hline $\mathrm{OC}_{\mathrm{T} 5}$ & 0.85 & 0.63 & 0.84 & 0.77 \\
\hline Mean (A) & 0.66 & 0.54 & 0.69 & \\
\hline LSD $_{0.05}$ & $A=0.02$ & $2 \mathrm{~B}=0.03$ & $\mathrm{~A} \times \mathrm{B}=$ & 0.059 \\
\hline
\end{tabular}

* N.S: not significant.

interactions in the two seasons, data showed that $\mathrm{OC}_{\mathrm{T} 1}$ gave low values of phosphorus in the leaves with all media. Meanwhile, $\mathrm{OC}_{\mathrm{T} 5}$ gave high values in sandy and peat moss media compared to calcareous medium. These result were in agreement with, Saadawy et al. (2005) on Peperomia, Schefflera and Syngonium, El-Sayed et al. (2012) on Freesia refracta, and AbdulHafeez et al. (2015) on Gardenia jasminoides.

\section{Potassium in the leaves (\%):}

Data in Table (21) showed that different media, organic compost treatments and their interactions had significant effects on that trait in the two seasons of study. With regard to different media, results presented in Table (21) showed that peat moss and sandy media gave statistically similar values, while gave higher value with calcareous as 2.09 and $2.38 \%$, respectively in the two seasons. Means of compost treatments Table (21) indicated that organic compost at $60 \%$ sugar beet and $60 \%$ rice straw gave highest percentage of potassium in leaves as 2.21,
Table 21. Effect of different media, organic compost and their interaction on potassium in the leaves (\%) of Gazania splendens during 2017 and 2018 seasons.

\begin{tabular}{|c|c|c|c|c|}
\hline \multirow{2}{*}{$\begin{array}{l}\text { Organic } \\
\text { compost } \\
\text { treatments } \\
\text { (B) }\end{array}$} & \multicolumn{3}{|c|}{ Media (A) } & \multirow[b]{2}{*}{$\begin{array}{c}\text { Mean } \\
\text { (B) }\end{array}$} \\
\hline & Sandy C & Calcareous & $\begin{array}{l}\text { Peat } \\
\text { moss }\end{array}$ & \\
\hline & \multicolumn{4}{|c|}{ First season } \\
\hline $\mathrm{OC}_{\mathrm{T} 1}$ & 1.06 & 1.40 & 1.32 & 1.26 \\
\hline $\mathrm{OC}_{\mathrm{T} 2}$ & 1.47 & 2.17 & 1.45 & 1.70 \\
\hline $\mathrm{OC}_{\mathrm{T} 3}$ & 1.96 & 2.17 & 2.05 & 2.06 \\
\hline $\mathrm{OC}_{\mathrm{T} 4}$ & 2.32 & 2.05 & 1.30 & 1.89 \\
\hline $\mathrm{OC}_{\mathrm{T} 5}$ & 2.13 & 2.67 & 1.84 & 2.21 \\
\hline Mean (A) & 1.79 & 2.09 & 1.59 & \\
\hline \multirow[t]{2}{*}{ LSD $_{0.05}$} & $A=0.25$ & $5 \quad \mathrm{~B}=0.30$ & $\mathrm{~A} \times \mathrm{B}=0$ & 0.59 \\
\hline & \multicolumn{4}{|c|}{ Second season } \\
\hline $\mathrm{OC}_{\mathrm{T} 1}$ & 1.20 & 1.59 & 1.50 & 1.43 \\
\hline $\mathrm{OC}_{\mathrm{T} 2}$ & 1.67 & 2.47 & 1.65 & 1.93 \\
\hline $\mathrm{OC}_{\mathrm{T} 3}$ & 2.23 & 2.47 & 2.33 & 2.34 \\
\hline $\mathrm{OC}_{\mathrm{T} 4}$ & 2.64 & 2.33 & 1.47 & 2.15 \\
\hline $\mathrm{OC}_{\mathrm{T} 5}$ & 2.42 & 3.04 & 2.10 & 2.52 \\
\hline Mean (A) & 2.03 & 2.38 & 1.81 & \\
\hline LSD $_{0.05}$ & $A=0.29$ & $9 \quad \mathrm{~B}=0.34$ & $A \times B=c$ & 0.52 \\
\hline
\end{tabular}

* N.S: not significant.

$2.52 \%$ and $2.06,2.34 \%$, respectively in the two seasons. With regard to the mean of potassium in leaves (\%) under the effect of different media and the compost treatment interactions in the both seasons. Data showed that $\mathrm{OC}_{\mathrm{TI}}$ gave stable response to all three media, whereas $\mathrm{OC}_{\mathrm{T} 4}$ had significantly highest percentage of potassium \% in leaves in sandy medium compared to calcareous and sandy media. $\mathrm{OC}_{\mathrm{T} 5}$ gave low values with peat moss compared to calcareous and sandy soil. These result were in agreement with those of Abou-Hussien (2012) on Origanum majorana, Mazher et al. (2012) on Amaranthus tricolor, Abou Seedo et al. (2014) on Salvia officinalis, and AbdulHafeez et al. (2015) on Gardenia jasminoides.

\section{REFERENCES}

Abdul-Hafeez, E.Y.; Ibrahim, O.H. and ElKeltawi, N.E. (2015). Reuse of wastewater from phosphate fertilizer factories can combat soil alkalinity and improve quality of potted gardenia (Gardenia jasminoides, Ellis). Journal of 


\section{A.H. El-Naggar et al.}

Biodiversity and Environmental Sciences, 6(3), 423-433.

Abou-Hussien, E.A.; EL-Koumey, Y.B.; ELShafiey, F.S. and Gohar, H.M.A. (2012). Effect of compost plant residues on newly reclaimed soils properties and its productivity. Minufiya Journal of Agriculture Research, 37(1): 231- 245.

Abou Seedo, Kh.F.; Salih, A.A. and Taha, A.A. (2014). Effect of three different growth media on yield and oil constituents of rosemary (Rosmarinus officinalis, L.) under protected agriculture conditions. Journal of Agriculture Science and Technology, 4: 395-403.

Afify, M.T.; Bahnasawy, A.H. and Ali, S.A. (2002). Effect of rice straw picking up method on the performance of a rectangular baler. In AIC 2002 Meeting, CSAE/SCGR Program, Saskatoon, Saskatchewan, July, pp. 14-17.

Algur, Ö.F. and Kadioğlu, A. (1992). The effects of vinasse on the growth, biomass and primary productivity in pea (Pisum sativum) and sunflower (Helianthus annuus). Agriculture, Ecosystem and Environment, 39(3-4):139-144.

Atta-Alla, H.K.; Zaghloul, M.A.; Baraka, M.M. and Hashish, K.H. (2003). Effect of organic manure and NPK fertilizers on the vegetative growth, flowering and chemical composition of some gladiolus cultivars. Annals of Agriculture Science, Moshtohor, 41(2):1121-1144.

Ball, V. (1991). Ball Red Book, $15^{\text {th }}$ ed. Geo. J. Ball Publishing, USA., 802 p.

Chapman, H.D. and Pratt, P.F. (1961). Methods of analysis for soils, plants and water. Agricultural Public University of California, Riverside, USA., 309 p.

Davis, J.G. and Wilson, C.R. (2005). Choosing a soil amendment. Colorado State University Cooperative ExtensionHorticulture. Bulletin, (7.235).
El-Nady, I.M.K. (2015). Physiological Studies on Lemongrass Plant. M.Sc. Thesis, Fac. Agric., Banha University, Egypt, 156 p.

El-Naggar, A.H. and El-Nasharty, A.B. (2009). Effect of growing media and mineral fertilization on growth, flowering, bulbs productivity and chemical constituents of Hippeastrum vittatum, herb. Merican-Eurasian Journal of Agriculture and Environment Science, 6(3):360- 371.

El-Sayed, A.; El Hanafy, H.S.; Nabih, A. and Atowa, D.I. (2012). Raising Freesia refracta cv. Red Lion corms from cormels in response to different growing media and actosol levels. Journal of Horticultural Science and Ornamental Plants, 4(1):89-97.

El-Sayed, S.G. (1991). Salt Tolerance Evaluation for Some Flowers and Ornamental Plants. M.Sc. Thesis, Faculty of Agriculture, Alexandria. University. Egypt, 81 p.

Evenhuis, B. and Dewaard, P.W. (1980). Principles and practices in plant analysis. FAO Soil Bull., 38:152-163.

Gad, M.M. (2003). Growth response of Schefflera actinophylla, harms plants to different planting media and paclobutrazol application. Assiut Journal of Agricultural Sciences Egypt, 34(3): 131-159.

Gomez, K.K. and Gomez, A.A. (1984). Statistical Procedures for Agricultural Research, $2^{\text {nd }}$ Ed. John Wiley and sons, New York, USA, 680 p.

Guo, X.; Gu, J.; Gao, H.; Qin, Q.; Chen, Z.; Shao, L. and Liu, J. (2012). Effects of $\mathrm{Cu}$ on metabolisms and enzyme activities of microbial communities in the process of composting. Bioresource Technology, 108: $140-148$.

Hendawy, S.F.; El-Sherbeny, E.S.; Badawy, M.E.; Hussein, S.M.; El-Kadya, F.Y.A. and Amer, M.H. (2015). Influence of fertilization on growth, yield and 
chemical constituents of Lallemantia iberica plant. World Journal of Pharmaceutics and Science, 3(5):9981012.

Idrovo-Novillo, J.; Gavilanes-Terán, I.; Veloz-Mayorga, N.; Erazo-Arrieta, R. and Paredes, C. (2019). Closing the cycle for the cut rose industry by the reuse of its organic wastes: A case study in Ecuador. Journal of Cleaner Production, 220: 910-918.

Mazher, A.A.M.; Mahgoup, M.H.; Abd ELRheem, Kh.M. and Zaghloul, S.M. (2012). Influence of nile compost application on growth, flowering and chemical composition of Amaranthus tricolor under different irrigation intervals. Middle-East Journal Science Research, 12(6):751- 759.

Mousa, G.T.; Habdul-Hafeez, E.Y. and Ibrahim, O.H.M. (2015). Response of gardenia plants grown under various growth media and ferrous sulfate application. Pakistan Journal Agricultural Science, 52(3):651-658.

Osman, M.A.; Seddik, W.M. and Youssef, G.H. (2008). Effect of some organic and natural conditioners addition on physical and chemical properties of soil, nutritional status and Zea maise yield. Journal of Agriculture Science, Mansoura University, 33(12):91883-9194.

Perner, H.; Schwarz, D.; Bruns, C.; Mäder, P. and George, E. (2007). Effect of arbuscular mycorrhizal colonization and two levels of compost supply on nutrient uptake and flowering of pelargonium plants. Mycorrhiza, 17(5):469-474.

Saadawy, F.; Rezk-Alla, B. and El-Fouly, A. (2005). Production of some indoor plants using natural local media. Journal Agricultural Science, Mansoura University, 30(12):8013-8035.

Sardoei, A.S.; Shahdadneghad, M.; RohanyYazdi, M. and Mohammadi, T. (2014). Effects of zinc sulphate and ascorbic acid on flowering characteristics of ornamental plant Gazania (Gazania rigens) cv. Daybreak Red Stripe. International Journal of Advanced Biological and Biomedical Research, 2(2):392-398.

Sherif, F.K. and EL-Naggar, A. (2005). Effect of biofertilizer application to manure on calla lily (Zantedeschia aethiopica, L. "Spring") production and nutrients release in sandy soil. Alexandria. Journal Agricultural Research, 50(1):181- 192.

Singh, P.V. (1999). Effect of organic and inorganic sources of nutrients on rainfall wheat. Indian Journal. Agronomy, 44 (2): 347- 352.

Soliman, T.M.A.; El-Keltawi, N.E.; Khan, M.A.; Nan, M. and Zhao, L. (2013). Plant growth and flowering of Cape Jasmine (Gardenia Jasminoides, Ellis) in various substrates amended with sulphut. Global Journal of Plant Ecophysiology, 3(2):36-43.

Soliman, W.S.A. (2005). Influence of Organic Matter Addition to Sandy Soil on Henna (Lawsonia alba, Lam.) Yield and Quality. M.Sc. Thesis, Faculty. Agricultural. Assiut University, Egypt, $126 \mathrm{p}$.

Vargas-Garcia, M.C.; Suarez-Estrella, F.; Lopez, M.J. and Moreno, J. (2010). Microbial population dynamics and enzyme activities in composting processes with different starting materials. Waste Management, 30(5): 771-778.

Yadava, U.L. (1986). A raped and nondestructive method to determined chlorophyll in intact leaves. Horticultural Science, 21(6):1449-1450.

Youssef, A.A.; Talaat, I.M. and Omer, E.A. (1998). Physiological response of basil green ruffles (Ocimum basilicum, L.) to nitrogen fertilization in different medias. Egyptian Journal of Horticulture, 25(2):253- 269. 


\section{A.H. El-Naggar et al.}

Youssef, A.M.; El-Fouly, A.H.M.; Youssef, M.S. and Mohamedien, S.A. (2001). Effect of using organic and chemical fertilizers in fertigation system on yield and fruit quality of tomato. Egyptian Journal of Horticulture, Egypt, 28: 59-77.

Youssef, S.A. (2008). Using Agricultural Wastes as Media for Planting Some
Ornamental Plants. Ph.D. Thesis, Fac. Agric., Ain Shams Univ., Egypt, 162 p.

Zeng, J.; Wang, D.; Wu, Y.; Guo, X.; Zhang, Y. and Lu, X. (2016). Karyotype analysis of Gazania rigens varieties. Horticultural Plant Journal, 2(5):279-283.

\section{الأستجابة الفسيولوجية لنباتات الجازانيا لبيئات النمو والكمبوست العضوى

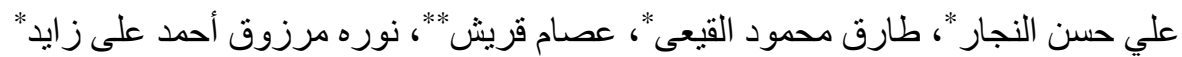

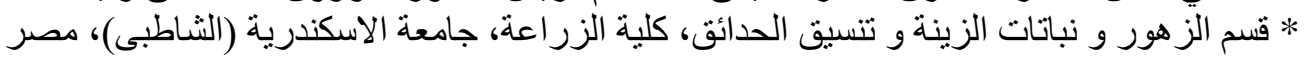

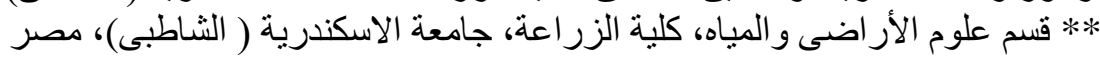

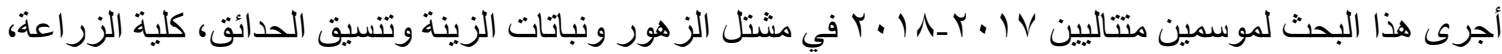

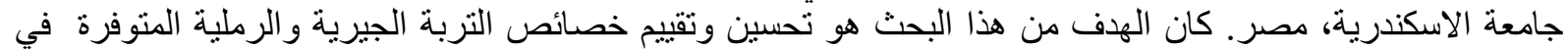

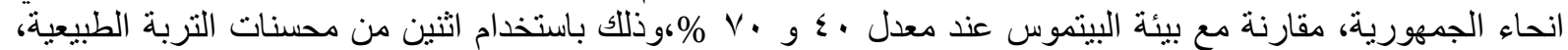

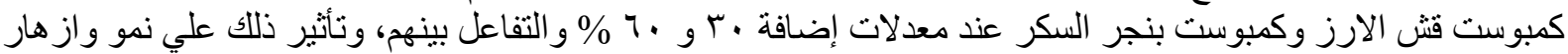

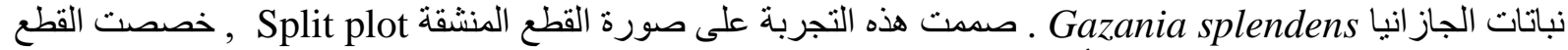
الكبيرة ( الرئيسية ) Main plots لأنو اع البيئات الثلاثة (رملية - جيرية - بيتموس) , في حين كانت معدلات الاضافيات

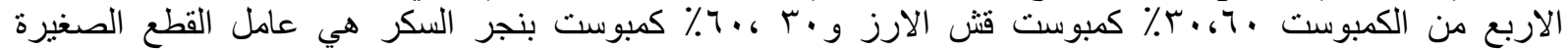

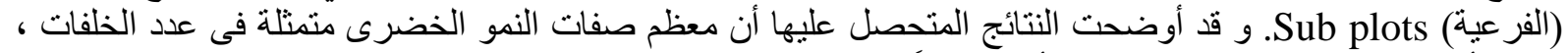



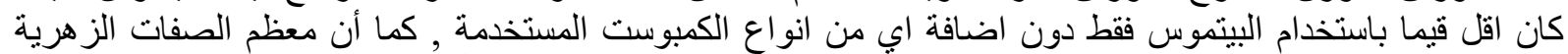

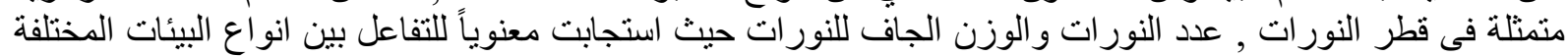

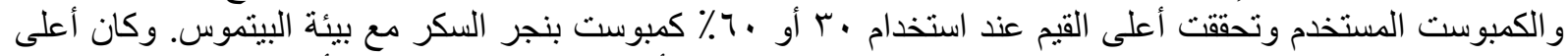

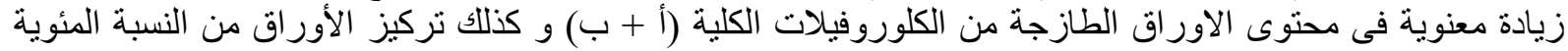

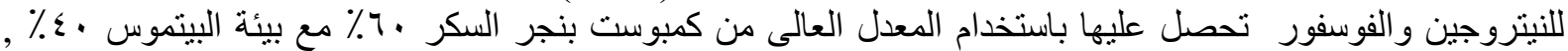

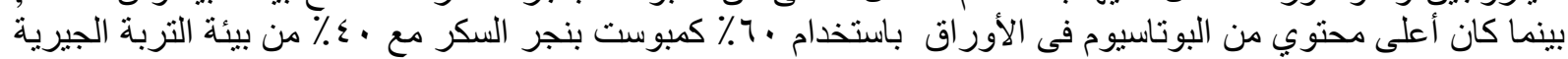

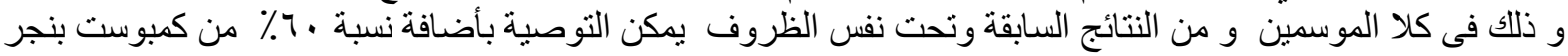

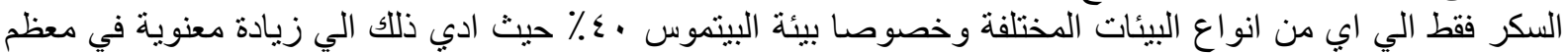

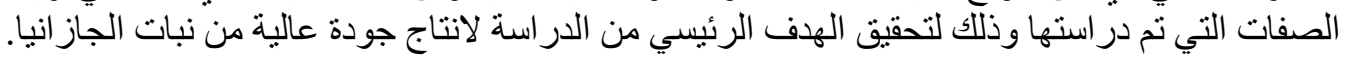

